\title{
Apakah Kadar $\beta$-hCG Praevakuasi dan Gambaran Proliferasi Sel Trofoblas secara Mikroskopik dapat digunakan untuk Prediksi Transformasi Keganasan pada Mola Hidatidosa?
}

\author{
Kemala Isnainiasih Mantilidewi, Zulvayanti, Wiryawan Permadi \\ Departemen Obstetri dan Ginekologi Fakultas Kedokteran Universitas Padjadjaran \\ Rumah Sakit Dr. Hasan Sadikin Bandung \\ Korespondesi: Kemala Isnainiasih Mantilidewi, Email: kemala.i.mantilidewi@unpad.ac.id
}

\begin{abstract}
Abstrak
Tujuan: Meneliti perbedaan karakteristik umur, paritas, besar uterus, kadar $\beta$-hCG, dan hiperproliferasi pada mola hidatidosa $(\mathrm{MH})$ dengan regresi spontan dan pada $\mathrm{MH}$ dengan transformasi keganasan di RS Dr. Hasan Sadikin Bandung.

Metode: Penelitian cross sectional deskriptif restrospektif mengambil data umur, paritas, besar uterus, kadar $\beta$-hCG pre-evakuasi, dan hiperproliferasi dari rekam medis pasien MH periode 2007-2016. Data diolah menggunakan program SPSS versi 20.0 for Windows. Nilai $p<0,05$ dianggap signifikan.

Hasil: Dari 400 rekam medis yang dianalisis, 233 dengan data lengkap dapat dianalisis. Mayoritas pasien usia reproduktif 20-35(53,6\%) tahun, paritas 1-2 ( $\mathrm{n}=90,38,6 \%)$, dan besar uterus rata-rata 19,12 $\pm 4,633(\sim \mathrm{ming}$ gu kehamilan). Kadar $\beta$-hCG $<100000 \mathrm{mIU} / \mathrm{mL}$ sebanyak 78(33,5\%), $\geq 100000 \mathrm{mIU} / \mathrm{mL}$ sebanyak 155(66,5\%). Pasien dengan hiperproliferasi sebanyak 83(35,6\%) sedangkan pasien tanpa hiperproliferasi sebanyak 150(64,4\%). Terdapat 219(94,0\%) dengan komplit $\mathrm{MH}$, dan 14(6,0\%) HM parsial (tidak dipublikasi). Pasien kemudian dikategorikan menjadi kelompok transformasi keganasan dan kelompok remisi spontan. Tidak terdapat perbedaan umur, paritas, dan besar uterus diantara dua kelompok $(\mathrm{p}>0,05)$. Perbedaan kadar $\beta \mathrm{hCG}(\mathrm{mIU} / \mathrm{mL})$ dan tingkat proliferasi menunjukkan hasil signifikan $(\mathrm{p}<0.05)$.

Kesimpulan: Kadar $\beta$-hCG preevakuasi dan status hiperproliferasi dapat digunakan sebagai prediktor transformasi keganasan pasien $\mathrm{MH}$.
\end{abstract}

Kata kunci: Mola hidatidosa, faktor risiko, remisi, transformasi keganasan

\section{Can Preevacuation Level $\beta$-hCG and Microscopic Trophoblast Proliferation Predict Malignant Transformation in Hydatidiform Mole?}

\footnotetext{
Abstract

Objective: To describe differences among age, parity, size of uterus, level of $\beta$ - $h C G$, and hyperproliferation state in $H M$ with spontaneous remission and in that with malignancy transformation at dr.Hasan Sadikin General Hospital Bandung.

Methods: This a cross sectional descriptive restrospective study of HM cases analyzing data on age, parity, size of uterus, pre-evacuation level of $\beta$ - $h C G$, and hyperproliferation state taken from medical record of HM patients between 2007-2016. Data were statistically analyzed using SPSS version 20.0 for Windows. Result $p<0.05$ was considered significant.

Results: Out of 400 cases, 233 cases were selected. Those with incomplete data were not included in the analysis. Majority of patients were in reproductive age 20-35(53.6\%) years old, has parity 1-2(n=90,38.6\%), and the size of uterus has mean 19.12 \pm 4.633 ( week of pregnancy). The level of $\beta-h C G<100000 \mathrm{mIU} / \mathrm{mL}$ was $78(33.5 \%), \geq 100000$ $\mathrm{mIU} / \mathrm{mL}$ was $155(66.5 \%)$. Patients with hyperproliferation were $83(35.6 \%)$ while without hyperproliferation were $150(64.4 \%)$. There were $219(94.0 \%)$ with complete HM, and 14(6.0\%) partial HM (unpublished data). There were no significant differences in age, parity, size of uterus between the two groups $(p>0.05)$. Differences on level of $\beta h C G(\mathrm{mIU} / \mathrm{mL})$ and proliferation state showed significant result $(p<0.05)$.

Conclusion: Preevacuation level of $\beta-h C G$ and histopatology (proliferation state) may predict malignancy transformation in HM.
}

Keywords: Hydatidiform mole, risk factors, remission, malignancy transformation 


\section{Pendahuluan}

Mola hidatidosa $(\mathrm{MH})$ adalah suatu kehamilan abnormal dengan sebagian atau seluruh vili korialisnya mengalami degenerasi hidropik berupa gelembung yang menyerupai anggur. Kondisi seluruh vili korialis mengalami degenerasi hidropik tanpa embrio disebut mola hidatidosa komplit (MHK) dan bila diantara gelembung ditemukan bagian janin disebut mola hidatidosa parsial (MHP). ${ }^{1-5}$ Insidensi MH cenderung menurun disebabkan penurunan fertilitas dan perbaikan gizi. Namun penurunan insidensi tidak disertai perbaikan karakteristik klinis karena di Indonesia masih ditemukan kasus-kasus dalam keadaan lanjut. ${ }^{53}$

Gizi, umur, ras, paritas, dan genetik dianggap sebagai faktor risiko mola hidatidosa, namun belum diketahui secara jelas faktor terjadinya transformasi keganasan mola hidatidosa menjadi tumor trofoblastik gestasional. ${ }^{4-6}$

Sampai saat ini kadar $\beta$-human chronic gonadotropin ( $\beta \mathrm{hCG})$ digunakan untuk memprediksi perkembangan transformasi keganasan pasca mola menjadi tumor trofoblastik gestasional (TTG) disebut sebagai koriokarsinoma klinis. ${ }^{3,4}$ Kadar $\beta$ hCG $>1000 \mathrm{mIU} / \mathrm{mL}$ merupakan faktor risiko tinggi sehingga beberapa center menetapkan pemberian kemoterapi profilaksis dan jika pada follow up terjadi distorsi penurunan kadar $\beta$ hCG dari kurva regresi kadar $\beta$ hCG dari Moschizuki. ${ }^{5-7}$

Penelitian ini menganalisis perbedaan karakteristik demografi (usia dan paritas), besar uterus, kadar $\beta$ hCG, dan proliferasi trofoblas berlebih pada $\mathrm{MH}$ dengan remisi spontan dan pada $\mathrm{MH}$ yang mengalami transformasi keganasan menjadi TTG di RSUP dr.Hasan Sadikin Bandung periode 2007-2016.

\section{Metode}

Penelitian ini merupakan suatu penelitian observasi analitik dengan cross sectional yang mengambil data rekam medis pasien di Rumah Sakit Umum Pusat (RSUP) dr.Hasan Sadikin-Fakultas Kedokteran Universitas Padjadjaran, Bandung, Indonesia periode 1 Januari 2007 sampai dengan 31 Desember 2016.

Data yang digunakan adalah demografi (usia dan paritas), besar uterus, kadar $\beta$-hCG preevakuasi, serta proliferasi berlebih jaringan mola. Data diambil dari rekam medis disajikan dalam bentuk tabel. Data kategorik disajikan dengan jumlah/frekuensi dan persentase sedangkan data numerik disajikan dengan rerata, median, standar deviasi dan range. Kategori ukuran uterus merupakan data numerik yang dianalisis menggunakan uji $\mathrm{T}$ tidak berpasangan apabila data berdistribusi normal serta uji alternatif Mann Whitney apabila data tidak berdistribusi normal. Analisis data kategorik yaitu usia, paritas, $\beta$-hCG, dan hiperproliferasi diuji dengan menggunakan uji statistik Chi-Square dan uji alternatif Exact Fisher apabila asumsi Chi Square tidak terpenuhi. Data diolah menggunakan program SPSS versi 20.0 for Windows. Nilai $\mathrm{p}<0,05$ dianggap signifikan.

\section{Hasil}

Dari 400 rekam medis yang dikumpulkan, terdapat 233 rekam medis yang termasuk kriteria inklusi, yaitu rekam medis dengan data pasien yang lengkap, yaitu data usia, paritas, ukuran uterus, kadar $\beta$-hCG preevakuasi, hasil PA dan hasil histopatologi (proliferasi berlebih). 
Tabel 1 Karakteristik Subjek Penelitian

\begin{tabular}{lc}
\hline \multicolumn{1}{c}{ Variabel } & $\mathbf{N}=\mathbf{2 3 3}$ \\
\hline Kategori Usia & \\
$<20$ & $22(9,4 \%)$ \\
$20-35$ & $125(53,6 \%)$ \\
$>35-40$ & $30(12,9 \%)$ \\
$\geq 40$ & $56(24,0 \%)$ \\
Paritas & \\
0 & $72(30,9 \%)$ \\
$1-2$ & $90(38,6 \%)$ \\
$\geq 3$ & $71(30,5 \%)$ \\
Ukuran Uterus ( minggu & \\
kehamilan) & \\
Rerata & $19,12 \pm 4,633$ \\
Median & 20,000 \\
Range (min-max) & $6,00-32,00$ \\
Kadar $\boldsymbol{\beta h C G}$ preevakuasi & \\
(mIU/mL) & \\
$<100.000$ & $78(33,5 \%)$ \\
$\geq 100.000$ & $155(66,5 \%)$ \\
Proliferasi & \\
Berlebih & $83(35,6 \%)$ \\
Tidak Berlebih & $150(64,4 \%)$ \\
\hline
\end{tabular}

Keterangan : Data kategorik disajikan dengan jumlah/ frekuensi dan persentase sedangkan data numerik disajikan dengan rerata, median, standar deviasi dan range.
Pada tabel 1 didapatkan hasil dari 233 pasien, mayoritas pasien pada usia produktif 20-35 $(53,6 \%)$, paritas $1-2(\mathrm{n}=90,38,6 \%)$ dan ukuran uterus 19.12 \pm 4.633 ( $\sim$ minggu kehamilan). Pasien dengan kadar $\beta$-hCG preevakuasi $<100000 \mathrm{mIU} / \mathrm{mL}$ sebanyak $78(33,5 \%)$ dan $\geq 100000 \mathrm{mIU} / \mathrm{mL}$ sebanyak 155 (66.5\%). Hasil histopatologi (proliferasi) berlebih sebanyak 83 (35.6\%) dan tidak berlebih 150 (64.4\%). Terdapat 219 (94.0\%) dengan hasil PA MHK, dan 14(6.0\%) MHP (data tidak tertulis).

Pasien kemudian dikelompokkan menjadi dua kelompok, yaitu pasien dengan transformasi keganasan dan dengan remisi spontan menurut pedoman RSHS. Pada Tabel 2 didapatkan hasil tidak terdapat perbedaan yang bermakna antara usia, paritas, dan ukuran uterus (minggu) pada kelompok transformasi keganasan dan remisi spontan. Perbandingan antara kadar $\beta$ hCG preevakuasi $(\mathrm{mIU} / \mathrm{mL})$ dan proliferasi berlebih pada kelompok transformasi keganasan dan remisi spontan didapatkan nilai $\mathrm{p}<0,001$ yang berarti signifikan atau bermakna secara statistik.

Tabel 2 Perbandingan antara Kategori Usia, Paritas, Ukuran Uterus ( minggu kehamilan) pada Kelompok Transformasi Keganasan dan Kelompok Remisi Spontan

\begin{tabular}{lccc}
\hline \multirow{2}{*}{ Variabel } & \multicolumn{2}{c}{ Kelompok } & \multirow{2}{*}{ Nilai p } \\
\cline { 2 - 3 } & $\begin{array}{c}\text { Transformasi } \\
\text { Keganasan }\end{array}$ & $\begin{array}{c}\text { Remisi } \\
\text { Spontan }\end{array}$ & \\
\cline { 2 - 3 } Kategori Usia (Tahun) & $\mathbf{N = 9 3}$ & $\mathbf{N = 1 4 0}$ & $\mathbf{0 , 7 0 1}$ \\
$<20$ & $8(8,6 \%)$ & $14(10,0 \%)$ & \\
$20-35$ & $53(57,0 \%)$ & $72(51,4 \%)$ & \\
$>35-40$ & $13(14,0 \%)$ & $17(12,1 \%)$ & \\
$\geq 40$ & $19(20,4 \%)$ & $37(26,4 \%)$ & \\
Paritas & & & $\mathbf{0 , 7 9 2}$ \\
0 & $30(32,3 \%)$ & $42(30,0 \%)$ & \\
$1-2$ & $37(39,8 \%)$ & $53(37,9 \%)$ & \\
$\geq 3$ & $26(28,0 \%)$ & $45(32,1 \%)$ & \\
Ukuran Uterus & & & $\mathbf{0 , 5 4 4}$ \\
( minggu kehamilan) & & & \\
Rerata (SB) & $18,68 \pm 5,311$ & $19,41 \pm 4,116$ & \\
Median & 20,000 & 20,000 & \\
& & &
\end{tabular}




\begin{tabular}{|c|c|c|c|}
\hline \multirow{3}{*}{ Variabel } & \multicolumn{2}{|c|}{ Kelompok } & \multirow{3}{*}{ Nilai p } \\
\hline & $\begin{array}{c}\text { Transformasi } \\
\text { Keganasan }\end{array}$ & $\begin{array}{l}\text { Remisi } \\
\text { Spontan }\end{array}$ & \\
\hline & $\mathrm{N}=\mathbf{9 3}$ & $\mathrm{N}=140$ & \\
\hline Rentang & $6,00-30,00$ & $8,00-32,00$ & \\
\hline $\begin{array}{l}\text { Kadar } \beta \text { hCG } \\
\text { preevakuasi }(\mathrm{mIU} / \mathrm{mL})\end{array}$ & & & $0,001 * *$ \\
\hline$<100.000$ & $13(14.0 \%)$ & $65(46.4 \%)$ & \\
\hline$\geq 100.000$ & $80(86.0 \%)$ & $75(53.6 \%)$ & \\
\hline Proliferasi & & & $0,001 * *$ \\
\hline Berlebih & $70(75.3 \%)$ & $13(9.3 \%)$ & \\
\hline Tidak Berlebih & $23(24.7 \%)$ & $127(90.7 \%)$ & \\
\hline
\end{tabular}

Keterangan : Data numerik, yaitu usia dan ukuran uterus diuji dengan uji alternatif Mann Whitney. Data kategorik usia, paritas, hasil PA, kadar $\beta$ hCG preevakuasi, dan proliferasi berlebih nilai p dihitung berdasarkan uji Chi-Square. Tanda** menunjukkan nilai $\mathrm{p}<0,001$ yang berarti signifkan atau bermakna secara statistik.

\section{Pembahasan}

Beberapa faktor risiko diketahui berperan dalam terjadinya $\mathrm{MH}$ yaitu umur, paritas, dan genetik., 4 Terdapat banyak kontroversi dari berbagai penelitian mengenai hubungan faktor ras dan paritas dengan MH. Beberapa penelitian menemukan kelompok usia $<20$ dan $>35$ tahun memiliki risiko lebih tinggi untuk terjadinya mola hidatidosa. Usia $>40$ tahun meningkatkan insidensi 4-10 kali lipat dibandingkan usia 20-40 tahun.

Besarnya ukuran uterus yang lebih besar dari usia kehamilan yang sesuai merupakan salah satu patognomonik $\mathrm{MH}$. Uterus membesar disebabkan oleh jaringan korion dan darah yang berkumpul dalam uterus. Pembesaran uterus dapat disebabkan oleh stimulasi $\beta$-hCG terhadap proliferasi trofoblas. ${ }^{6}$ Kadar $\beta$-hCG merupakan indikator prediksi perkembangan mola hidatidosa pada follow up, juga sebagai dasar pemberian terapi profilaksis maupun terapi TTG. Kadar $\beta$-hCG sebagai prediksi adanya pertumbuhan jaringan baru mola pasca evakuasi menurut Mochizuki dkk adalah $\geq 1000 \mathrm{mIU} / \mathrm{mL}$ pada minggu ke- $4, \geq 100 \mathrm{mIU} / \mathrm{mL}$ pada minggu ke- 6 , dan $\geq 30 \mathrm{mIU} / \mathrm{mL}$ pada minggu ke- 8 . $^{5,6,7}$ Mola hidatidosa pasca evakuasi dapat masih menunjukkan aktivitas trofoblastik berlebih yang dalam beberapa kepustakaan disebut dengan koriokarsinoma klinis., ${ }^{4,9}$ Di RSHS koriokarsinoma dapat didiganosis secara klinis, yaitu bila $>1000 \mathrm{mIU} / \mathrm{mL}$ pada minggu ke-4, $>100 \mathrm{mIU} / \mathrm{mL}$ pada minggu ke- 6 , dan $>30 \mathrm{mIU} / \mathrm{mL}$ pada minggu ke- $8 .{ }^{10}$

Dari hasil penelitian ini dapat disimpulkan kadar $\beta$ hCG preevakuasi $(\mathrm{mIU} / \mathrm{mL})$ dan proliferasi berlebih terdapat perbedaan signifikan antara kelompok dengan transformasi keganasan dan remisi spontan sehingga kedua faktor ini merupakan faktor risiko penting yang dapat mempengaruhi prognosis pasien dengan HM. Simpulan Kadar $\beta$-hCG preevakuasi dan proliferasi berlebih dapat digunakan untuk sebagai faktor prediksi transformasi keganasan.

\section{Daftar Pustaka}

1. Yamamoto E, NiimiK, Kiyono T, Yamamoto T, Nishino K, Nakamura K, Kotani T, Kajiyama H, Shibata K, Kikkawa F. Establishment and characterization of cell lines derived from complete hydatidiform mole. Int J Mol Med. 2017;40(3):614-22.

2. de Souza JM, Braga A, dos Santos RS, Ramos MM, Cortés-Charry R, Maestá I. Comparison of 2 Human Chorionic Gonadotropin Immunoassays Commercially Available for Monitoring Patients With Gestational Trophoblastic 
Disease. In $\mathrm{J}$ Gynecol Cancer. 2017;27(7):1494-500.

3. Lurain JR. Gestational trophoblastic disease I: epidemiology, pathology, clinical presentation and diagnosis of gestational trophoblastic disease, and management of hydatidiform mole. Am J Obstet Gynecol. 2010;203(6):531.

4. Sebire NJ LI, Fisher RA. Overdiagnosis of complete and partial hydatidiform mole in tubal ectopic pregnancies. Int J Gynecol Pathol. 2005;24(3):260.

5. Martaadisoebrata D. Buku pedoman pengelolaan penyakit trofoblas gestasional Edisi. Jakarta: EGC; 2005.

6. Bratakoesoema DS. Penyakit trofoblas gestasional. Dalam: Aziz MF, Andrijono, Saifuddin AB, penyunting. Buku acuan nasional onkologi.Edisi. Jakarta: Yayasan Bina Pustaka Sarwono Prawirohardjo; 2006. h. 532-568.

7. Ngan $\mathrm{H}$, Bender $\mathrm{H}$, Benedet $\mathrm{J}$, Jones $\mathrm{H}$, Montruccoli G, Pecorelli S, dkk.
Gestational trophoblastic neoplasia, FIGO 2000 staging and classification. Int J Gynaecol Obstet. 2003;83:175.

8. Martaadisoebrata D. Protokol pengelolaan penyakit trofoblas gestasional. Edisi ke1. Bandung: Pusat Pengelolaan Penyakit Trofoblas Gestasional; 2005.

9. Nishi H, Nakada T, Hokamura M, Osakabe $\mathrm{Y}$, Itokazu $\mathrm{O}$, Huang LE, Isaka $\mathrm{K}$. Hypoxia-inducible factor-1 transactivates transforming growth factor- $\beta 3$ in trophoblast. Endocrinol. 2004 Sep 1;145(9):4113-8.

10.Emerling BM, Weinberg F, Liu JL, Mak TW, Chandel NS. PTEN regulates p300dependent hypoxia-inducible factor 1 transcriptional activity through Forkhead transcription factor 3a (FOXO3a). Proc Natl Acad Sci USA. 2008 Feb 19;105(7):2622-7. 